\title{
Cognitive, Affective and Behavioral Investigation of Turkish People's Attitudes Towards the COVID-19 Pandemic Quarantine Process
}

\author{
Türk Halkının COVID-19 Pandemisi Karantina Sürecine Yönelik Tutumlarııın Bilişsel, \\ Duyuşsal ve Davranışsal Boyutta Incelenmesi
}

\author{
(D) Berkalp TUNCA ${ }^{1}$, (D) Ece ÖZGÖREN² , (D) insan BERK ${ }^{3}$, (D) Buket IPEK ${ }^{4}$, (D) Mustafa DEMiR ${ }^{1}$, (D) Nefise FERMANCI ${ }^{1}$, (D) Şevkiye BABACAN¹, \\ (D) Murat AKŞiT55, (D) Yemliha DURMAZ5 ${ }^{\text {, (D) Cengiz GAZELOĞLU6 }}$, (D) Sinan SARAÇLI7 \\ ${ }^{1}$ Afyon Kocatepe University, Institute of Science, Department of Statistics, Afyonkarahisar, Turkey \\ ${ }^{2}$ Eskişehir Technical University, Institute of Science, Department of Statistics, Eskişehir, Turkey \\ ${ }^{3}$ Sanko University, Faculty of Medicine, Department of Biostatistics, Gaziantep, Turkey \\ ${ }^{4}$ Karadeniz Technical University, Institute of Science and Technology, Department of Statistics, Trabzon, Turkey \\ 5 Private Sector, istanbul, Turkey \\ 6Süleyman Demirel University, Faculty of Arts and Sciences, Department of Statistics, Isparta, Turkey \\ ${ }^{7}$ Afyon Kocatepe University, Faculty of Arts and Sciences, Department of Statistics, Afyonkarahisar, Turkey
}

\begin{abstract}
Aim: The aim of study is to determine the attitude of the Turkish people (in cognitive, affective and behavioral dimensions) and the factors affecting this attitude during the coronavirus epidemic that has affected the whole world since December 2019.

Materials and Methods: The data collected by a scale were modeled with explanatory factor analysis (EFA), confirmatory factor analysis (CFA) and structural equation modeling (SEM), and the effects of the dimensions and the importance of the effective items in each dimension were determined.

Results: $61.4 \%$ of the participants were male and $65.4 \%$ were under the age of 40 years. Individuals' "questioning their purpose of coming to life again" and "desire of being more sensitive to the events around them than in the past" were found to be significant, respectively. Other results obtained from the study are given in the relevant tables and figures.

Conclusion: It was determined that the affective dimension had the highest effect on the results of EFA, CFA and SEM analyses, which were effective in examining the attitudes of individuals towards an event with these sub-dimensions.
\end{abstract}

Keywords: COVID-19, epidemic processes, attitude and behavior, statistical modeling

ÖZ

Amaç: Bu çalışmanın amacı, Aralık 2019'dan beri tüm dünyayı etkisi altına alan koronavirüs salgını süresince Türk halkının sergilediği tutumu (bilişsel, duyuşsal ve davranışsal boyutlarda) ve bu tutum üzerinde etkili olan etmenleri belirlemektir.

Gereç ve Yöntem: Bir ölçek aracılığı ile derlenen veriler açıklayıcı faktör analizi (AFA), doğrulayıcı faktör analizi (DFA), yapısal eşitlik modellemesi (YEM) ile modellenerek, boyutlar arası ilişkiler ile her bir boyutta etkili olan maddelerin önemleri belirlenmiştir.

Bulgular: Katılımcıların \%61,4'ü erkek ve \%65,4'ü 40 yaş altıdır. Bireylerin tutumlarını açıklayan alt boyutlardan davranışsal boyut üzerinde bireylerin ekonomik tedbirlere vereceği önemin en etkili değişken olduğu, bilişsel ve duyuşsal boyutlarda ise sırası ile bireylerin hayata geliş amaçlarını tekrar

Address for Correspondence: Cengiz GAZELOĞLU MD, Süleyman Demirel University, Faculty of Arts and Sciences, Department of Statistics, Isparta, Turkey Phone: +90 2462114353 E-mail: cengizgazeloglu@sdu.edu.tr ORCID ID: orcid.org/0000-0002-8222-3384

Received: 06.01.2021 Accepted: 09.03.2021 
sorgulamaları ve çevrelerindeki olaylara karşı geçmiştekinden daha duyarlı olacaklarının önemi anlamlı bulunmuştur. Çalışmadan elde edilen diğer sonuçlar ilgili tablo ve şekillerde verilmiştir.

Sonuç: Bireylerin bir olaya karşı olan tutumlarının bu alt boyutlar ile incelenmesi noktasında etkili olan istatistiksel yöntemlerden AFA, DFA ve YEM analizi sonuçlarında duyuşsal boyutun etkisinin en yüksek olduğu belirlenmiştir.

Anahtar Kelimeler: COVID-19, salgın süreçleri, tutum ve davranış, istatistiksel modelleme

\section{INTRODUCTION}

In our country, the time spent at home has increased within the scope of the measures taken after the first coronavirus disease-2019 (COVID-19) case observed on March $11^{\text {th }}$. It has been observed that our citizens' awareness and sensitivities on some issues have increased. In addition, it is observed that the shares they make through social media have increased and they question their purpose of life and the values they give to their loved ones. While many individuals state that they have accomplished the things they wanted to do but did not have the opportunity to do before due to the hustle and bustle of life, it should not be overlooked that each of them has shared how important it is to be able to walk freely on the street, to eat at a restaurant and to drink tea in a cafe with their friends, without realizing it. Depending on these, it is seen that they express how important social solidarity is and that material things such as the house, the car, etc do not mean anything without humanity and it is remarkable that there has been an increase in shares about that they support aid campaigns for people in economic difficulties and that they are more sensitive towards street animals during this period. While some people are bored with staying at home, some people have to work without the luxury of staying at home because they provide for their families and the contribution of their work to this process is indispensable, the importance of which has been well-understood. In addition to these, it is another remarkable point that although people understand the importance of their health once again, they are psychologically tense with the fear of facing the deadly virus as a result of the slightest carelessness, and that intra-familial conflicts have increased both around the world and in our country.

All these indicators can be evaluated as a result of individuals' attitudes towards daily events, which differ in cognitive, affective and behavioral dimensions in this process. In this context, the aim of this study is to reveal the differences related to these dimensions both at the national and international levels and to contribute to humanity by emphasizing the importance of the positive and negative variables that cause it.

The research hypotheses of the study are given as items below.

1. What are the cognitive attitudes of individuals towards the COVID-19 pandemic quarantine process?
2. What are the affective attitudes of individuals towards the COVID-19 pandemic quarantine process?

3. What are the behavioral attitudes of individuals towards the COVID-19 pandemic quarantine process?

4. Is there a significant difference among individuals'cognitive, affective and behavioral attitudes towards the COVID-19 pandemic quarantine process?

5. Do individuals' attitudes towards the COVID-19 pandemic quarantine process differ significantly according to their demographic characteristics?

6. Do individuals' cognitive and affective attitudes towards the COVID-19 pandemic quarantine process have a significant effect on their behaviors?

\section{Literature Review}

Although the origin of the word pandemic is a combination of the Greek words "pan" (all) and "demos" (people), this word is often used for epidemic infectious diseases that are widespread in the whole country or in one or more continents at the same time'.

However, the use of this word with its definition in many medical texts has been neglected in the last 20 years. This word did not find a place in the indexes of many authoritative studies and texts about the pandemic, even in comprehensive sources on the history of medicine, in classical epidemiological sources, and in the effective infections report of the institute of medicine in $1992^{2}$. Internationally accepted known and common definition of pandemic in the epidemiology dictionary is "an epidemic that occurs worldwide, or that originates in large areas and transcends international borders, affecting large masses of people" 3,4 .

Among all known pandemic pathogens, influenza (flu infection) has been the main cause since the $16^{\text {th }}$ century due to its potential seriousness and irregular occurrence ${ }^{5,6}$.

In all other pandemics and the COVID-19 pandemic process, the most effective individual measures, apart from the measures taken by the administration, can be listed as giving maximum importance to hygiene, eating natural and healthy, increasing mobility and exercise, and paying attention to social isolation? ${ }^{7}$. At this point, the importance of education 
shows itself once again. The higher the number of conscious individuals in a society as a result of education, the higher the probability of success in the fight against epidemics. In this context, it should be emphasized that by creating a permanent awareness, people should act in line with ethical values and care about other people's lives.

It is known that it is easier to fight the pandemic in societies where healthy individuals are in the majority, and it has also been observed during the COVID-19 process and in the past that individuals with a healthy immune system are more likely to win the struggle for their lives, even if the virus is transmitted.

In the COVID-19 process, it is seen that the ethics in the behavior of individuals who make up all societies with their physicians, scientists, politicians affect the period we live in. The COVID-19 pandemic offers us an opportunity to reconsider our values, from individual ethics to social ethics, from professional ethics to political ethics. In this process, it has been realized that we need to balance the value of life and the profitability of the capitalist system in terms of bioethics and environmental ethics, and that the policies we create with human-centered thinking cannot be isolated from other life forms ${ }^{8}$.

\section{The Effects of Pandemic on Human Attitudes and Behaviors}

When people are faced with a contagious disease epidemic, they can take some preventive actions against the negative effects of the epidemic in terms of health and economy to reduce the risk they face ${ }^{9}$.

Studies in the literature on behavioral responses to the flu epidemic can be found in related sources ${ }^{9-12}$. There are many theories about risk perception, such as protection motivation theory (PMT) ${ }^{13}$, health belief model ${ }^{14}$, extended parallel process mode $l^{15}$ and precaution adoption process mode ${ }^{16}$. The basic idea on which these theories are based is that people react to any threat. PMT distinguishes two phases called assessment of threat and assessment of coping. Assessment of threat is perceived personal susceptibility (or perceived vulnerability) combining states of fear for the threat (belief in the possibility of contracting the disease) and for perceived severity of the threat (having a serious feeling of contracting the disease). Assessment of coping is defined as variables related to the proposed protection response.

These are the perceived response effect (What protective behaviors will help?), the individual effect on the perceived response (Am I a confident person to exhibit protective behaviors?), and the consequences of the reactions (What are the disadvantages of protective behaviors?). According to PMT, assessment of the threat triggers the intention to act, while assessment of coping triggers the type of behavior exhibited ${ }^{17}$. Following the SARS epidemic that emerged in 2003, a population-based hypothetical study on people's protective measures in an influenza epidemic was conducted in 3 Asian and 5 European countries ${ }^{9}$. With some exceptions, the potential protective measures in each country were similar for individuals. Even in places where the risk was low, public transport was often cited as the most risky factor for disease transmission. Participants stated that in the event of a new epidemic, they would stay away from public transportation, entertainment places and shopping centers unless they are of vital importance. Participants also stated that although they cared about the high risk of contamination, they did not hesitate to go to health institutions. Moreover, participants working in one job stated that they took less protective measures than others. Interestingly, risk perception variables did not significantly affect their precautionary behaviors. They were only sensitive about public transportation ${ }^{17}$.

Available knowledge, attitudes, and belief systems about the risk associated with a disease may change over time. Mathematical models are a powerful tool for estimating the potential contagiousness of disease and for investigating effective control measures. For models with a complex structure, it has also been shown that contagion can be prevented by preventing direct interaction of other individuals with this network if individual precautions are taken sufficiently considering infected individuals in the social network ${ }^{18}$. There are increasing efforts to motivate people to maintain social distance and to limit their interaction with other people and accordingly the risk of social diseases. Social distancing is not a new concept and has been used for centuries to quarantine infected individuals and avoid illness, but new approaches must be introduced to deal with modern social interactions ${ }^{19}$. Although it is imperative to provide a balance between informing the public and not creating panic ${ }^{20}$, the community expects the latest up-to-date information and timely and satisfactory explanations of what and why to do from administrators ${ }^{21-23}$.

During the COVID-19 epidemic, which is still ongoing in our country, compulsory measures were taken by the state on issues such as maintaining a distance of at least 1 meter and using masks in public transportation, public and common social areas, and announcements and statements were made about raising a general awareness among citizens.

It is an inevitable fact that all these effects experienced during the COVID-19 process cause people to re-judge their values in their lives. From this point of view, it is thought that the attitudes exhibited in this process are also effective for the future periods and it is aimed to determine the factors that have effects on the attitudes of individuals in this study. 


\section{Concept of Attitude}

Attitude is not a directly observable feature, but a tendency attributed to that individual by inferring from the observable behaviors of the individual. In other words, an attitude is not a behavior that can be observed, but a tendency to prepare for behavior. The tendency of a person to show positive or negative behavior towards any event, object or person is called attitude. A mental assessment is the minimum requirement for a trend to be considered as an attitude, but most established attitudes that people develop over time include affective and behavioral elements. In other words, attitudes cannot be observed directly, but are revealed by the individual's other behaviors ${ }^{24-26}$. According to Fishbein and Ajzen ${ }^{27}$, behavioral, affective and cognitive elements must be in a consistent relationship with each other in the formation of attitude ${ }^{28}$. Smith ${ }^{29}$ has explained the concept of attitude as "the tendency that is attributed to the individual and that regularly forms the thoughts, feelings and behaviors of the individual about a psychological object".

Attitude is expressed as learned self-tendency, which appears in the form of being for or against a concrete object or an abstract concept, and directs the thoughts and feelings of the individual ${ }^{30}$. According to Petty and Cacciopo ${ }^{31}$, attitudes are people's general evaluations of themselves, others, or other objects, events, or problems. These general assessments are based on many behaviors, affective and cognitive bases and affect their developments, changes and formations ${ }^{32}$. According to Thurstone ${ }^{33}$, an attitude is a positive or negative intensity ranking and rating directed towards a psychological object. It is accepted by scientists that some variables play a role in the formation of attitude, and scientists examine and express these variables in different ways. Middlebrook, on the other hand, admits that attitude has three components ${ }^{34}$. These components are expressed as follows ${ }^{35}$ :

1. Cognitive Component: It is the individual's thoughts and beliefs about the attitude.

2. Affective Component: It is the individual's liking or disliking of the subject of attitude.

3. Behavioral Component: It is the behavior of the individual regarding the subject of attitude.

The cognitive element is the rational component of attitudes consisting of ideas, knowledge and beliefs. The affective component includes positive (happiness, joy, appreciation and satisfaction) and negative feelings and emotions (regret, anger, boredom, fear, etc.) rather than neutral information. The behavioral element, on the other hand, expresses the tendency of an attitude to turn into a behavior ${ }^{36,37}$. Bloom ${ }^{38}$ has revealed that affective features increase the cognitive achievement in the relevant area by about a quarter, that is, about a quarter of the variability in learning success is due to affective features ${ }^{35}$. The behavioral component expresses the tendency of an attitude to turn into a behavior ${ }^{36}$. The behavioral element reflects the tendency to act in accordance with the affective and cognitive elements and it is action-oriented ${ }^{37,39}$.

Although Qiu et al. ${ }^{4}$ examined the effects of the pandemic in their studies by considering them in health, economy, social and security dimensions, these dimensions will be evaluated as cognitive, affective and behavioral dimensions of the attitudes of individuals during their stay at home due to the COVID-19 pandemic in this study.

\section{MATERIALS AND METHODS}

In this study, it was primarily aimed to develop a new scale to determine the attitudes of Turkish people towards the COVID-19 pandemic quarantine process in cognitive, affective and behavioral dimensions. In this process, the evaluations of 10 scientists from different universities were taken to determine the expert opinions. These factors, namely cognitive, affective and behavioral dimensions, were examined with explanatory factor analysis (EFA), Confirmatory Factor Analysis (CFA) and structural equation model (SEM). The questionnaire used in the study was approved by the decision of Afyon Kocatepe University Scientific Research and Publication Ethics Committee dated 27.05.2020 and numbered 15.06.2020-E.17011.

\section{Statistical Analysis}

Statistical methods were used to determine the statistical validity and reliability of the item pool created for the attitude scale, and the internal consistency of the scale for the reliability analysis was determined by the Cronbach alpha coefficient. In order to determine the sub-dimensions and the items collected in these dimensions in this scale, whose validity and reliability were ensured, EFA was applied to the relevant data set and the obtained dimensions were tested with CFA again. Finally, the dimensions affecting the behavior of individuals during the COVID-19 process were modeled with SEM, and the interdimensional relations and the importance of the items that were effective in each dimension were determined. Statistical Package for the Social Sciences and LISREL programs were used in the analysis of the data used in the study.

\section{Explanatory Factor Analysis}

EFA can be defined as a multivariate statistics that aims to find and discover a small number of conceptually significant new variables (factors, dimensions) by bringing together a large number of interrelated variables. Factor analysis operates on the notion that measurable and observable variables can be reduced to fewer latent variables that share a common variance and are unobservable, which is known as reducing 
dimensionality ${ }^{40}$. Rennie ${ }^{41}$, on the other hand, defines EFA as an analytical technique with a computational logic based on the relationships between observed variables, aiming to reach a small number of explanatory factors (concepts) that explain the maximum variance ${ }^{42}$.

\section{Confirmatory Factor Analysis}

When we review the literature in general, it is seen that CFA is a method that is mostly applied after classical factor analysis studies ${ }^{43,44}$. In such studies, the researchers subject the factor structures that they have determined with the EFA study to CFA. Thus, although it is a highly accepted practice, such practices actually contradict the nature of the SEM somewhat. Because here, in a sense, it is about testing the factor structures that the data set has directed us. However, it should be noted right away that although the exploratory factor analysis results of studies that do not have a strong theoretical basis are very good, frustration can be experienced in the phase of CFA.

\section{Structural Equation Model}

SEM is a statistical technique that is used to test the causal relationships between observed and unobserved (latent) variables, and analyzes especially latent variables with both dependent and independent variables in detail. It has also proven to be a useful technique in solving problems encountered in formulating theoretical structures. It is a systematic tool used especially in psychology, sociology, marketing and educational sciences to evaluate the relationships between variables and to test theoretical models. Technically, SEM is used to estimate the unknown parameters in the linear structure equation set. The variables in the equations are usually latent variables that are directly related to the observed variables.

SEM assumes that there is a causality structure between the set of latent variables and that latent variables can be measured through observed variables ${ }^{45}$.

It gives better results than other multivariate statistical techniques such as multiple regression, path analysis and factor analysis. Other statistical techniques fail to take into account the interactions between dependent and independent variables. SEM can also present statistical efficiency and explanatory ability ${ }^{46,47}$ in a model test with a single comprehensive method. SEM is a method that predicts and tests by revealing the linear relationships of the theoretical connection between the variables $^{48,49}$.

\section{RESULTS}

As a result of the data compiled from the questionnaire included in the study, descriptive statistics are given in Table 1,2 and 3.
According to Table 2, 61.4\% of the participants were male and $65.4 \%$ were under the age of 39 years. While $29.2 \%$ did not have a fixed income, $70.8 \%$ had minimum wage or higher income. $76.1 \%$ had undergraduate and graduate degrees, $23.9 \%$ were primary, secondary, high school and associate degree graduates. In addition, while the rate of individuals who had COVID-19 positive people around themselves was $26.7 \%$, the rate of those who did not have was $73.3 \%$.

According to Table 3, when the averages of affective, cognitive and behavioral attitudes of the participants were examined in terms of gender, it was seen that the averages of women (4.21, $3.33,3.75)$ were higher than the averages of men $(3.97,3.10$, 3.69).

When the averages of affective attitudes were examined in terms of age groups, the averages of individuals between the ages of 20 and 39 years (4.16 for those aged $20-29$ years and 4.14 for those aged 30-39 years) were found to be higher than those of other age groups (4.05 for those aged 19 years and below, 4.07 for those aged 40-49 years, 4.05 for those aged 50 years and over). However, when the averages of cognitive attitudes were examined, it was seen that the averages of the participants aged 19 years and younger (3.47) were higher than the averages of the other age groups (3.22 for those aged 20-29 years, 3.24 for those aged $30-39$ years, 3.20 for those aged $40-49$ years, 3.25 aged 50 years and above). On the other hand, in the behavioral dimension, the averages of individuals aged 30 years and over ( 3.80 for those aged $30-39$ years, 3.89 for those aged 40-49 years, 3.85 for those aged 50 years and above) were higher than those of participants in other age groups ( 3.71 for those aged 19 years and below, 3.56 for those aged 20-29 years).

When the averages of affective attitudes were examined in terms of income level, the averages of the participants who did not have a fixed income (4.14) and those with an income of 4001-7000 TL (4.15) were observed to be higher compared to the averages of participants with other income levels (4.00 for minimum wage, 4.08 for $2000-4000$ TL, 4.08 for $7001-10000$ $\mathrm{TL}, 4.00$ for $10001 \mathrm{TL}$ and above).

When the cognitive attitude averages were examined, it was seen that the averages of the participants who did not have a fixed income (3.28) and who had an income between 2000 TL and 7000 TL (3.25 for 2000-4000 TL, 3.28 for 4001-7000 $\mathrm{TL})$ were higher than those of participants with other income levels (3.11 for minimum wage, 3.14 for 7001-10000 TL).

In addition, it is seen that the average of the cognitive attitudes of the participants whose income level is $10001 \mathrm{TL}$ and above has a negative attitude with 2.81. In the behavioral dimension, the averages of the participants with an income level of 4001 TL and above (3.76 for 4001-7000 TL, 3.84 for 7001-10000 


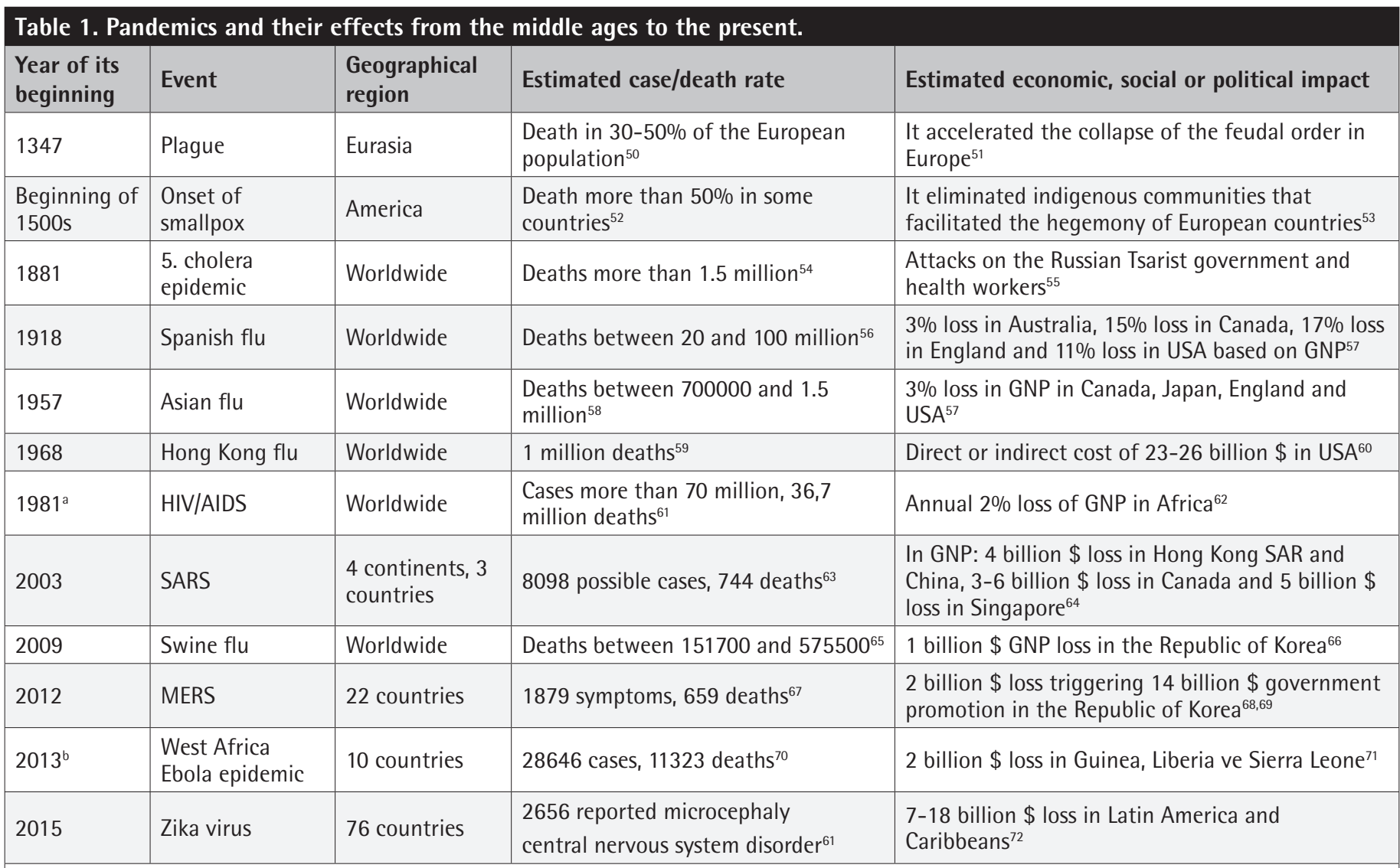

The effects of studies about HIV/AIDS on gross national product per capita were a little. ${ }^{6}$ The West African Ebola Epidemic was seen between 2013 and 2016, but in 2014, it peaked and international effects were observed. GNP: Gross national product, HIV/AIDS: Human immuno deficiency virus/acquired immuno deficiency syndrome, MERS: Middle east respiratory syndrome, SARS: Severe acute respiratory syndrome, reference ${ }^{6}$

TL, 3.74 for 10001 and above) were found to be higher than those of participants with other income levels (3.68 for those without a fixed income, 3.61 for minimum wage, 3.69 for 2000-4000 TL).

When the averages of affective, cognitive and behavioral attitudes were examined in terms of education level, it was seen that the averages of individuals who were primary school graduates were higher than the averages of those with other education levels. In addition, considering the affective dimension, it was seen that the average was above 4 for every education level except secondary school graduates.

While it was found that the average of the participants with COVID-19 positive individuals in their close environment was 4.18 in the affective dimension, 3.24 in the cognitive dimension, and 3.71 in the behavioral dimension, the average of the participants who did not have COVID-19 positive individuals in their close environment was 4.09 in the affective dimension, 3.24 in the cognitive dimension and 3.73 in the behavioral dimension.

In addition, although the general average of the affective dimension was 4.12, the general average of the cognitive dimension was 3.24 , and the general average of the behavioral dimension was 3.72 , it was observed that the participants exhibited a positive attitude.

EFA results are given in Table 4.

According to Table 4, of the items that made up the affective dimension, for the item of affective (DUY1) "I have realized the meaning of life more", the factor load was 0.849 and the mean was 4.19; for the item of DUY2 "I have understood how valuable health is", the factor load was 0.814 and the mean was 4.40; for the item of DUY3 "My sensitivity to social issues has increased", the factor load was 0.788 and the mean was 4.03; for the item of DUY4 "I have realized that I should value the people I love more", the factor load was 0.703 and the mean was 3.97; for the item of DUY5 "I have understood the importance of the activities I did with my friends", the factor load was 0.659 and the mean was 4.18; for the item of DUY6 "I think that I will be a more sensitive individual in the future to events that I ignored in the past", the factor load was 0.619 and the mean was 3.98; and for the item of DUY7 "I was more worried about my close environment than myself", the factor load was found to be 0.568 and the mean was 4.07. In addition, the affective dimension factor explains $24.587 \%$ of the total variance. Of the items that made up the cognitive dimension, for the item of cognitive (BIL1) "My religious awareness has 
Table 2. Frequency and percentage values for the participants

\begin{tabular}{|c|c|c|}
\hline Demographic variables & Frequency & Percentage (\%) \\
\hline \multicolumn{3}{|l|}{ Gender } \\
\hline Female & 588 & 61.4 \\
\hline Male & 370 & 38.6 \\
\hline \multicolumn{3}{|l|}{ Age } \\
\hline 19 years and below & 55 & 5.7 \\
\hline $20-29$ years & 373 & 38.9 \\
\hline $30-39$ years & 199 & 20.8 \\
\hline $40-49$ years & 150 & 15.7 \\
\hline 50 years and above & 181 & 18.9 \\
\hline \multicolumn{3}{|l|}{ Income level } \\
\hline No fixed income & 280 & 29.2 \\
\hline Minimum wage & 39 & 4.1 \\
\hline 2000-4000 TL & 154 & 16.1 \\
\hline 4001-7000 TL & 368 & 38.4 \\
\hline 7001-10000 TL & 79 & 8.2 \\
\hline $10001+$ & 38 & 4.0 \\
\hline \multicolumn{3}{|l|}{ Education level } \\
\hline Primary school & 11 & 1.1 \\
\hline Secondary school & 15 & 1.6 \\
\hline High school & 124 & 12.9 \\
\hline Associate degree & 79 & 8.2 \\
\hline Undergraduate degree & 539 & 56.3 \\
\hline Graduate degree & 190 & 19.8 \\
\hline \multicolumn{3}{|c|}{$\begin{array}{l}\text { The presence of any individual with positive COVID-19 in close } \\
\text { environment }\end{array}$} \\
\hline No & 702 & 73.3 \\
\hline Yes & 256 & 26.7 \\
\hline Total & 958 & - \\
\hline
\end{tabular}

increased", the factor load was 0.894 and the mean was 2.96; for the item of BIL2 "My commitment to my religion has increased", the factor load was 0.828 and the mean was 3.07; for the item of BIL3 "The importance I attach to material has decreased", the factor load was 0.735 and the mean was 3.24; for the item of BIL4 "I have once again questioned my purpose of life", the factor load was 0.727 and the mean was 3.36; and for the item of BIL5 "I have realized that money is not everything", the factor load was 0.639 and the mean was 3.58. In addition, the cognitive dimension factor explains $20.147 \%$ of the total variance. From the items that made up the behavioral dimension, for the item of behavioral (DAV1) "I have limited my expenses as much as possible", the factor load was 0.846 and the mean was 3.62; for the item of DAV2 "I have increased my economic measures", the factor load was 0.806 and the mean was 3.71 ; for the item of DAV3 "I have tried to keep my expenses under control", the factor load was 0.752 and the mean was 3.79; for the item of DAV4 "I have avoided unnecessary shopping", the factor load was 0.600 and the mean was 3.49; for the item of DAV5 "I have provided my own transportation way instead of public transportation", the factor load was 0.551 and the mean was 4.02; for the item of DAV6 "I have paid attention to a healthy diet", the factor load was 0.545 and the mean was 3.72 . The behavioral dimension factor explains $20.064 \%$ of the total variance. In addition, these 3 factors explain $64.798 \%$ of the total variance.

When Figure 1 is examined, it is seen that the most effective variable affecting the cognitive dimension factor is BIL4 "I have once again questioned my purpose of life" with a coefficient of 0.81 . The cognitive dimension factor is affected by the item of BIL3 "The importance I attach to material has decreased" with a coefficient of 0.80 , by the item of BIL1 "My religious awareness has increased" with a coefficient of 0.77 , by the item of BIL5 "I have realized that money is not everything" with a coefficient of 0.68 , and by the item of BIL2 "My commitment to my religion has increased" with a coefficient of 0.66 . It is seen that it also fulfills the criterion of $\mathrm{X}^{2} / \mathrm{df}=6.44 / 3=2.14<3$ which is among the criteria of goodness of fit.

According to Table 5, the composite reliabilit (CR) value of the cognitive dimension factor is 0.86 and the average variance extracted (AVE) value is 0.56 . The CR value is expected to be greater than 0.70 and the AVE value to be greater than 0.50 and it is seen that the values calculated here are in accordance with these criteria.

When Figure 2 is examined, the most effective variable affecting the affective dimension factor is DUY1 "I have realized the meaning of life more" with a coefficient of 0.79 . The affective dimension factor is affected by the item of DUY4 "I realized that I should value the people I love more" with a coefficient of 0.77 , by the item of DUY2 "I have realized how valuable health is" with a coefficient of 0.75 , by the item of DUY3 "My sensitivity to social issues has increased" with a coefficient of 0.74 , by the item of DUY6 "I think that I will be a more sensitive individual in the future to events that I ignored in the past" with a coefficient of 0.72 , by the item of DUY 5 "I have understood the importance of the activities I did with my friends" with a coefficient of 0.69 , and by the item of DUY7 "I was more worried about my close environment than myself" with a coefficient of 0.57 . It is seen that it also fulfills the criterion of $\mathrm{X}^{2} / \mathrm{df}=13.26 / 8=1.65<3$ which is among the criteria of goodness of fit.

According to Table 6 , the $C R$ value of the affective dimension factor is 0.88 and the AVE value is 0.52 . The CR value is expected to be greater than 0.70 and the AVE value to be greater than 0.50 and it is seen that the values calculated here are in accordance with these criteria. 


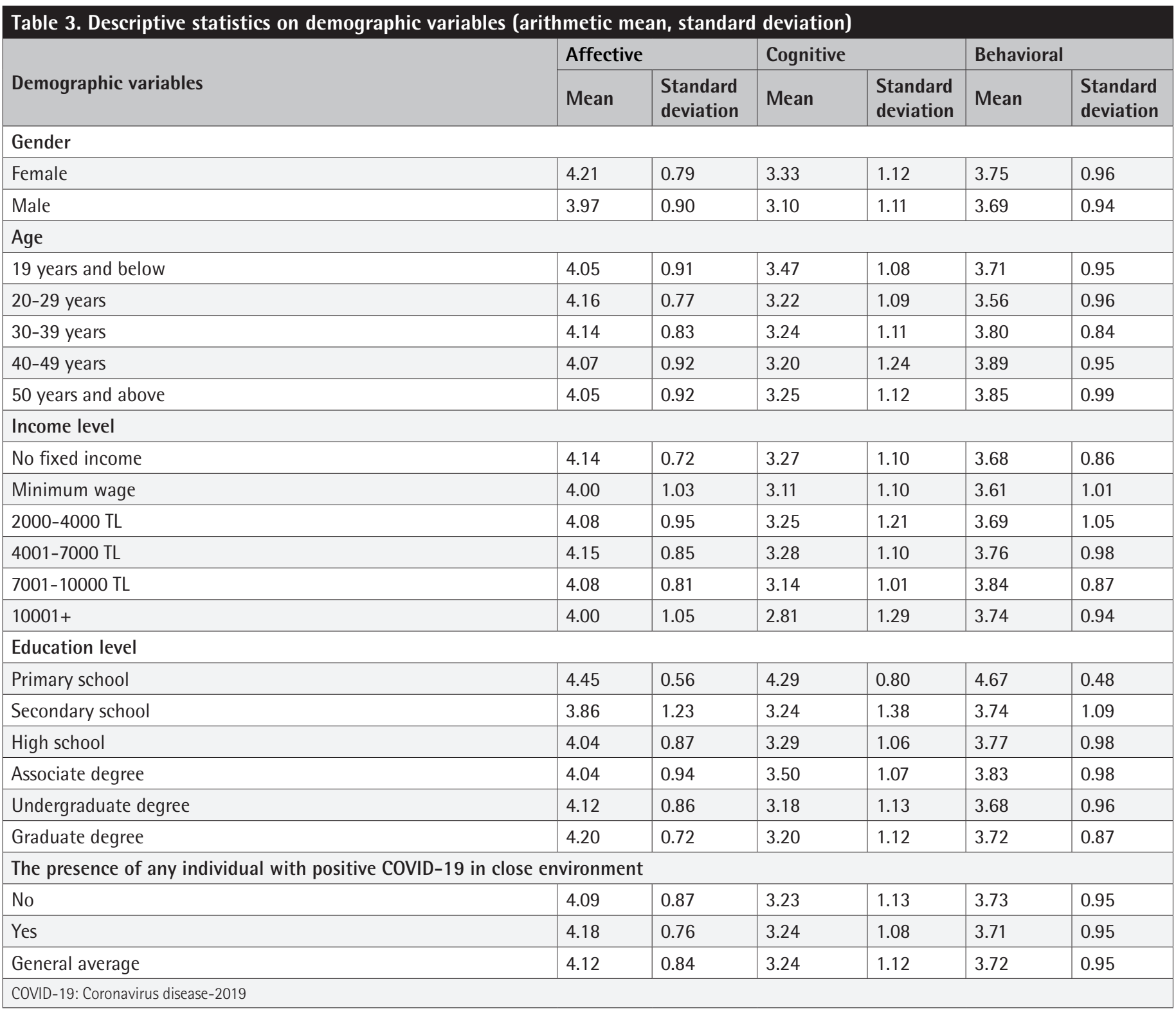

When Figure 3 is examined, the most effective variable affecting the behavioral dimension factor is seen to be DAV1 "I have limited my expenses as much as possible" with a coefficient of 0.93. The behavioral dimension factor is affected by the item of DAV2 "I have increased my economic measures" with a coefficient of 0.84 , by the item of DAV3 "I have tried to keep my expenses under control" with a coefficient of 0.74 , by the item of DAV6 "I have paid attention to a healthy diet" with a coefficient of 0.74 , by the item of DAV4 "I have avoided unnecessary shopping" with a coefficient of 0.54 , and by the item of DAV5 "I have provided my own transportation way instead of public transportation" with a coefficient of 0.51 .

It is seen that it also fulfills the criterion of $X^{2} / d f=12.75 / 5=2.55$ $<3$, which is among the criteria of goodness of fit.

According to Table 7, the $\mathrm{CR}$ value of the behavioral dimension factor is 0.87 and the AVE value is 0.54 . The CR value is expected to be greater than 0.70 and the AVE value to be greater than 0.50 and it is seen that the values calculated here are suitable for these criteria.

According to Table 8, the root mean square error of approximation (RMSEA) (0.035), normed fit index (NFI) (1.00), non-normed fit index (NNFI) (1.00), comparative fit index (CFI) (1.00), standardized root mean square residual (SRMR) (0.0064), goodness of fit index (GFI) (1.00) and adjusted goodness of fit index (AGFI) (0.99) values of the cognitive dimension factor are within the limits of excellent goodness of fit. The RMSEA (0.026), NFI (1.00), NNFI (1.00), CFI (1.00), SRMR (0.0087), GFI (1.00) and AGFI (0.99) values of the affective dimension factor are within the limits of excellent goodness of fit. For the behavioral dimension factor, the values of RMSEA (0.040), NFI (1.00), NNFI (0.99), CFI (1.00), SRMR (0.015), GFI (1.00) and AGFI (0.98) are within the limits of excellent goodness of fit. 
Table 4. EFA, reliability analysis and descriptive statistics of the scale

\begin{tabular}{|c|c|c|c|c|c|c|}
\hline \multicolumn{2}{|c|}{ Factors/items } & Factor loads & \multicolumn{2}{|c|}{$\begin{array}{l}\text { Total correlation for } \\
\text { corrected items }\end{array}$} & $\begin{array}{l}\text { Cronbach alpha val- } \\
\text { ue if item is deleted }\end{array}$ & $\overline{\mathbf{X}} \pm \mathrm{SD}$ \\
\hline \multicolumn{7}{|c|}{ DUY eigenvalue: 8.357} \\
\hline \multicolumn{7}{|c|}{ Variance explanation rate: $24.587 \%$} \\
\hline DUY1 & I have realized the meaning of life more & 0.849 & \multicolumn{2}{|l|}{0.668} & 0.925 & $4.19 \pm 1.01$ \\
\hline DUY2 & I have understood how valuable health is & 0.814 & \multicolumn{2}{|l|}{0.629} & 0.926 & $4.40 \pm 0.93$ \\
\hline DUY3 & My sensitivity to social issues has increased & 0.788 & \multicolumn{2}{|l|}{0.611} & 0.926 & $4.03 \pm 1.06$ \\
\hline DUY4 & $\begin{array}{l}\text { I have realized that I should value the people I love } \\
\text { more }\end{array}$ & 0.703 & \multicolumn{2}{|l|}{0.628} & 0.925 & $3.97 \pm 1.15$ \\
\hline DUY5 & $\begin{array}{l}\text { I have understood the importance of the activities I } \\
\text { did with my friends }\end{array}$ & 0.659 & \multicolumn{2}{|l|}{0.682} & 0.924 & $4.18 \pm 1.05$ \\
\hline DUY6 & $\begin{array}{l}\text { I think that I will be a more sensitive individual in the } \\
\text { future to events that I ignored in the past }\end{array}$ & 0.619 & \multicolumn{2}{|l|}{0.735} & 0.923 & $3.98 \pm 1.11$ \\
\hline DUY7 & $\begin{array}{l}\text { I was more worried about my close environment than } \\
\text { myself }\end{array}$ & 0.568 & \multicolumn{2}{|l|}{0.544} & 0.927 & $4.07 \pm 1.19$ \\
\hline \multicolumn{7}{|c|}{ BIL eigenvalue: 1.852} \\
\hline \multicolumn{7}{|c|}{ Variance explanation rate: $20.147 \%$} \\
\hline BIL1 & \multicolumn{2}{|l|}{ My religious awareness has increased } & 0.864 & 0.598 & 0.926 & $2.96 \pm 1.39$ \\
\hline BIL2 & \multicolumn{2}{|l|}{ My commitment to my religion has increased } & 0.828 & 0.549 & 0.927 & $3.07 \pm 1.38$ \\
\hline BIL3 & \multicolumn{2}{|l|}{ The importance I attach to material has decreased } & 0.735 & 0.668 & 0.924 & $3.24 \pm 1.34$ \\
\hline BIL4 & \multicolumn{2}{|l|}{ I have once again questioned my purpose of life } & 0.727 & 0.657 & 0.925 & $3.36 \pm 1.37$ \\
\hline BIL5 & \multicolumn{2}{|l|}{ I have realized that money is not everything } & 0.639 & 0.665 & 0.924 & $3.58 \pm 1.33$ \\
\hline \multicolumn{7}{|c|}{ DAV eigenvalue: 1.455} \\
\hline \multicolumn{7}{|c|}{ Variance explanation rate: $20.064 \%$} \\
\hline DAV1 & \multicolumn{2}{|l|}{ I have limited my expenses as much as possible } & 0.846 & 0.642 & 0.925 & $3.62 \pm 1.22$ \\
\hline DAV2 & \multicolumn{2}{|l|}{ I have increased my economic measures } & 0.806 & 0.658 & 0.925 & $3.71 \pm 1.22$ \\
\hline DAV3 & \multicolumn{2}{|l|}{ I have tried to keep my expenses under control } & 0.752 & 0.698 & 0.924 & $3.79 \pm 1.20$ \\
\hline DAV4 & \multicolumn{2}{|l|}{ I have avoided unnecessary shopping } & 0.600 & 0.556 & 0.927 & $3.49 \pm 1.28$ \\
\hline DAV5 & \multicolumn{2}{|l|}{$\begin{array}{l}\text { I have provided my own transportation way instead of public } \\
\text { transportation }\end{array}$} & 0.551 & 0.531 & 0.928 & $4.02 \pm 1.27$ \\
\hline DAV6 & \multicolumn{2}{|l|}{ I have paid attention to a healthy diet } & 0.545 & 0.628 & 0.925 & $3.72 \pm 1.20$ \\
\hline \multicolumn{7}{|c|}{ Total variance explanation rate: $64.798 \%$} \\
\hline \multicolumn{7}{|c|}{ SD: Standard deviation, DUY: Affective, BIL: Cognitive, DAV: Behavioral } \\
\hline
\end{tabular}

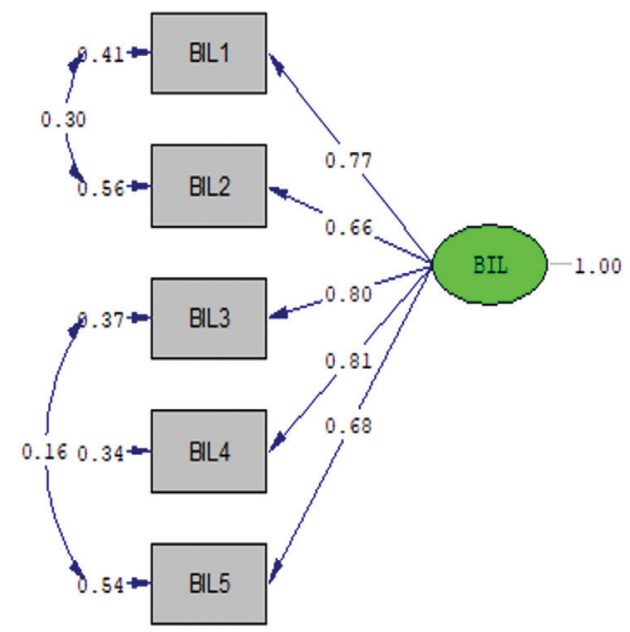

Chi-Square=6.44, df=3, P-value=0.09221, RMSEA=0.035

Figure 1. CFA model of cognitive dimension factor

CFA: Confirmatory factor analysis, BIL: Cognitive, RMSEA: Root mean square error of approximation
Table 5. For the items of cognitive dimension factor, findings on $\lambda, t$ value and $C R$ and AVE values

\begin{tabular}{|l|l|l|l|l|l|}
\hline $\begin{array}{l}\text { Latent } \\
\text { variable }\end{array}$ & $\begin{array}{l}\text { Observed } \\
\text { variable }\end{array}$ & $\lambda$ & t value & CR & AVE \\
\hline \multirow{5}{*}{ BIL } & - & - & - & 0.86 & 0.56 \\
\cline { 2 - 5 } & BIL1 & 0.77 & 25.67 & & \\
\cline { 2 - 4 } & BIL2 & 0.66 & 20.94 & & \\
\cline { 2 - 4 } & BIL3 & 0.80 & 26.72 & & \\
\cline { 2 - 4 } & BIL4 & 0.81 & 27.55 & & \\
\cline { 2 - 4 } & BIL5 & 0.68 & 21.28 & \\
\hline \multirow{2}{*}{ BIL: Cognitive, CR: Composite reliabilit, AVE: Average variance extracted } \\
\hline
\end{tabular}

Level 2 CFA results of cognitive, affective and behavioral dimensions, which are sub-dimensions of attitude, are given in Figure 4.

The SEM model established with cognitive, affective and behavioral dimensions is given in Figure 5 .

According to Figure 4, the most influential variable affecting the cognitive dimension factor was the item of BIL4 "I have 


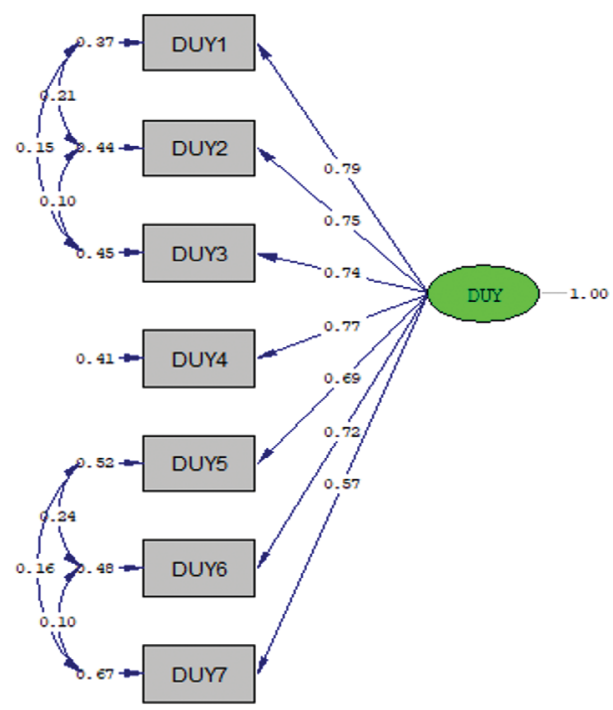

Chi-Square=13.26, df=8, P-value=0.10313, RMSEA $=0.026$

Figure 2. CFA model of affective dimension model

CFA: Confirmatory factor analysis, DUY: Affective, RMSEA: Root mean square error of approximation

Table 6. For the items of affective dimension factor, findings on $\lambda, t$ value and CR and AVE values

\begin{tabular}{|l|l|l|l|l|l|}
\hline $\begin{array}{l}\text { Latent } \\
\text { variable }\end{array}$ & $\begin{array}{l}\text { Observed } \\
\text { variable }\end{array}$ & $\lambda$ & t value & CR & AVE \\
\hline \multirow{5}{*}{ DUY } & & & & 0.88 & 0.52 \\
\cline { 2 - 4 } & DUY1 & 0.79 & 26.02 & & \\
\cline { 2 - 4 } & DUY2 & 0.75 & 23.80 & & \\
\cline { 2 - 4 } & DUY3 & 0.74 & 23.49 & \\
\cline { 2 - 4 } & DUY4 & 0.77 & 25.55 & \\
\cline { 2 - 4 } & DUY5 & 0.69 & 22.16 & \\
\cline { 2 - 4 } & DUY6 & 0.72 & 23.26 & & \\
\cline { 2 - 4 } & DUY7 & 0.57 & 17.30 & & \\
\cline { 2 - 4 } DUY: Affective, CR: Composite reliabilit, AVE: Average variance extracted
\end{tabular}

once again questioned my purpose of life" with a coefficient of 0.88 . The cognitive dimension factor is affected by the item of BIL5 "I have realized that money is not everything" with a coefficient of 0.84 , by the item of BIL3 "The importance I attach to material has decreased" with a coefficient of 0.83 , by the item of BIL1 "My religious awareness has increased" with a coefficient of 0.66, and by the item of BIL2 "My commitment to my religion has increased" with a coefficient of 0.58 .

It is seen that the most effective variable affecting the affective dimension factor is the item of DUY6 "I think that I will be a more sensitive individual in the future to events that I ignored in the past" with a coefficient of 0.80 . The affective dimension factor is affected by the item of DUY1 "I have realized the meaning of life more" with a coefficient of 0.74 , by the item

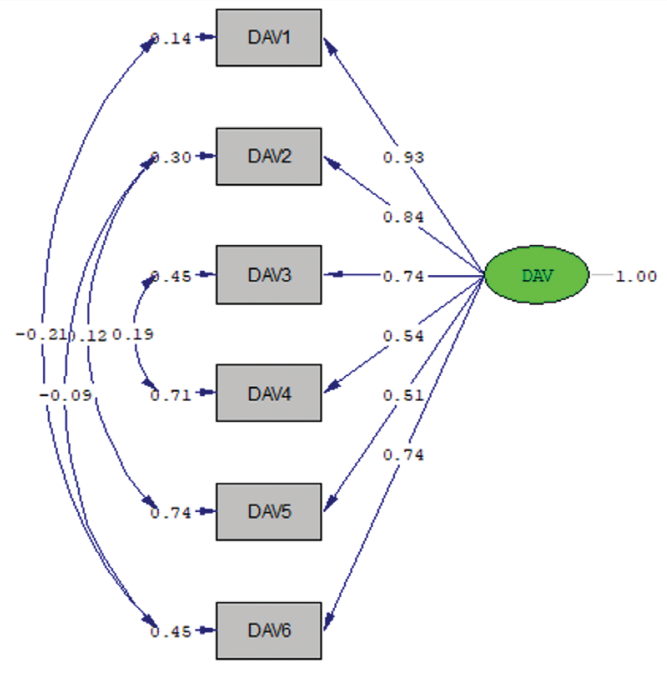

Chi-Square=12.75, df $=5, P-v a l u e=0.02584$, RMSEA $=0.040$

Figure 3. CFA model of behavioral dimension factor CFA: Confirmatory factor analysis, DAV: Behavioral, RMSEA: Root mean square error of approximation

Table 7. For the items of behavioral dimension factor, findings on $\lambda, t$ value and $C R$ and AVE values

\begin{tabular}{|l|l|l|l|l|l|}
\hline $\begin{array}{l}\text { Latent } \\
\text { variable }\end{array}$ & $\begin{array}{l}\text { Observed } \\
\text { variable }\end{array}$ & $\lambda$ & t value & CR & AVE \\
\hline \multirow{5}{*}{ DAV } & - & - & - & 0.87 & 0.54 \\
\cline { 2 - 4 } & DAV1 & 0.93 & 35.00 & & \\
\cline { 2 - 4 } & DAV2 & 0.84 & 30.24 & & \\
\cline { 2 - 4 } & DAV3 & 0.74 & 26.04 & & \\
\cline { 2 - 4 } & DAV4 & 0.54 & 17.58 & & \\
\cline { 2 - 4 } & DAV5 & 0.51 & 16.61 & & \\
\cline { 2 - 4 } & DAV6 & 0.74 & 21.40 & & \\
\hline \multicolumn{5}{|l}{ DAV: Behavioral, CR: Composite reliabilit, AVE: Average variance extracted } \\
\hline
\end{tabular}

Table 8. Findings on the goodness-of-fit criteria of CFA models established for cognitive, affective and behavioral factors

Goodness-

\begin{tabular}{|l|l|l|l|l|l|}
$\begin{array}{l}\text { Goodness- } \\
\text { of-fit } \\
\text { criteria }\end{array}$ & Excellent fit & $\begin{array}{l}\text { Acceptable } \\
\text { fit }\end{array}$ & BIL & DUY & DAV \\
\hline RMSEA & $\begin{array}{l}0<\text { RMSEA } \\
<0.05\end{array}$ & $\begin{array}{l}0.05 \leq \mathrm{RMSEA} \\
\leq 0.10\end{array}$ & 0.035 & 0.026 & 0.040 \\
\hline $\mathrm{NFI}$ & $0.95 \leq \mathrm{NFI} \leq 1$ & $\begin{array}{l}0.90<\mathrm{NFI} \\
\leq 0.95\end{array}$ & 1.00 & 1.00 & 1.00 \\
\hline $\mathrm{NNFI}$ & $0.97 \leq \mathrm{NNFI} \leq 1$ & $\begin{array}{l}0.95 \leq \mathrm{NNFI} \\
\leq 0.97\end{array}$ & 1.00 & 1.00 & 0.99 \\
\hline $\mathrm{CFI}$ & $0.97 \leq \mathrm{CFI} \leq 1$ & $\begin{array}{l}0.95 \leq \mathrm{CFI} \\
\leq 0.97\end{array}$ & 1.00 & 1.00 & 1.00 \\
\hline SRMR & $\begin{array}{l}0 \leq \mathrm{SRMR} \\
<0.05\end{array}$ & $\begin{array}{l}0.05 \leq \mathrm{SRMR} \\
\leq 0.10\end{array}$ & 0.0064 & 0.0087 & 0.015 \\
\hline GFI & $0.95 \leq \mathrm{GFI} \leq 1$ & $\begin{array}{l}0.90 \leq \mathrm{GFI} \\
\leq 0.95\end{array}$ & 1.00 & 1.00 & 1.00 \\
\hline AGFI & $0.90 \leq \mathrm{AGFI} \leq 1$ & $\begin{array}{l}0.85 \leq \mathrm{AGFI} \\
\leq 0.90\end{array}$ & 0.99 & 0.99 & 0.98 \\
\hline CA:Con
\end{tabular}

CFA: Confirmatory factor analysis, BIL: Cognitive, DUY: Affective, DAV: Behavioral, RMSEA: Root mean square error of approximation, NFI: Normed fit index, NNFI: Nonnormed fit index, CFI: Comparative fit index, SRMR: Standardized root mean square residual, GFI: Goodness of fit index, AGFl: Adjusted goodness of fit index 


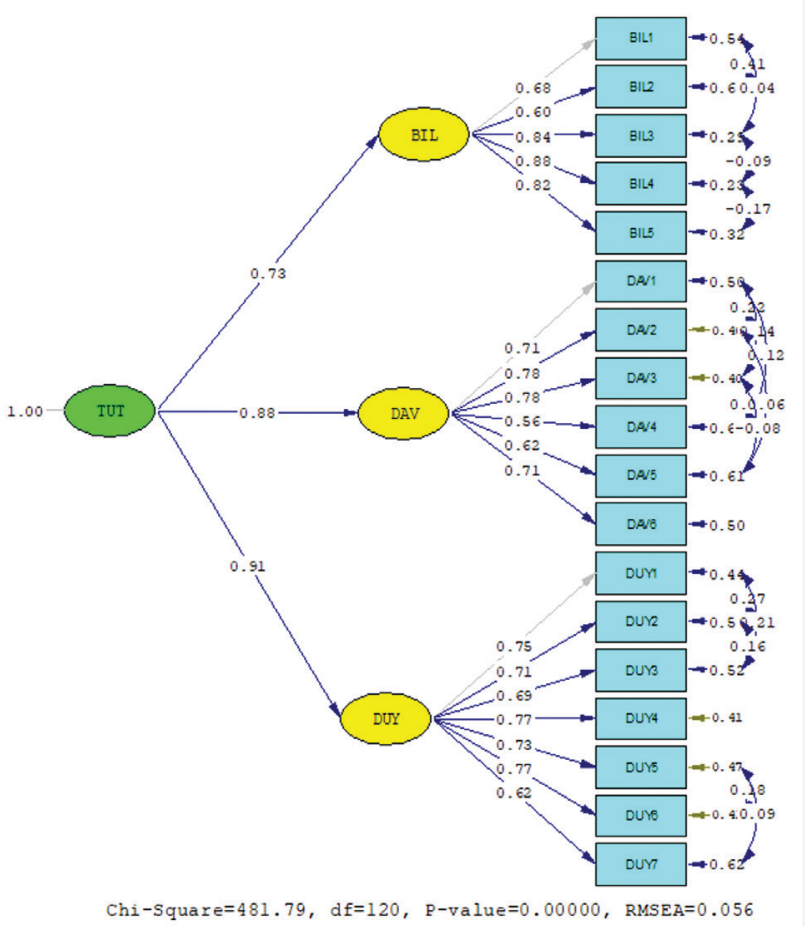

Figure 4. Second level confirmatory factor analysis results for cognitive, affective and behavioral dimensions

BIL: Cognitive, DUY: Affective, DAV: Behavioral, RMSEA: Root mean square error of approximation

of DUY4 "I have realized that I should value the people I love more" with a coefficient of 0.74 , by the item of DUY 5 "I have understood the importance of the activities I did with my friends" with a coefficient of 0.74 , by the item of DUY2 "I have understood how valuable health is" with a coefficient of 0.70 , by the item of DUY3 "My sensitivity to social issues has increased" with a coefficient of 0.69 , and by the item of "I was more worried about my close environment than myself" with a coefficient of 0.61 .

With a coefficient of 0.81 , the most influential variable affecting the behavioral dimension factor was DAV3 "I have tried to keep my expenses under control" The behavioral dimension factor is affected by the item of DAV2 "I have increased my economic measures" with a coefficient of 0.76 , by the item of DAV1 "I have limited my expenses as much as possible" with a coefficient of 0.72 , by the item of DAV6 "I have paid attention to a healthy diet" with a coefficient of 0.70 , by the item of DAV4 "I have avoided unnecessary shopping" with a coefficient of 0.70 , and by the item of DAV5 "I have provided my own transportation way instead of public transportation" with a coefficient of 0.62 .

In addition, affective dimension (0.55) affects behavioral dimension more than cognitive dimension (0.29). It is seen that

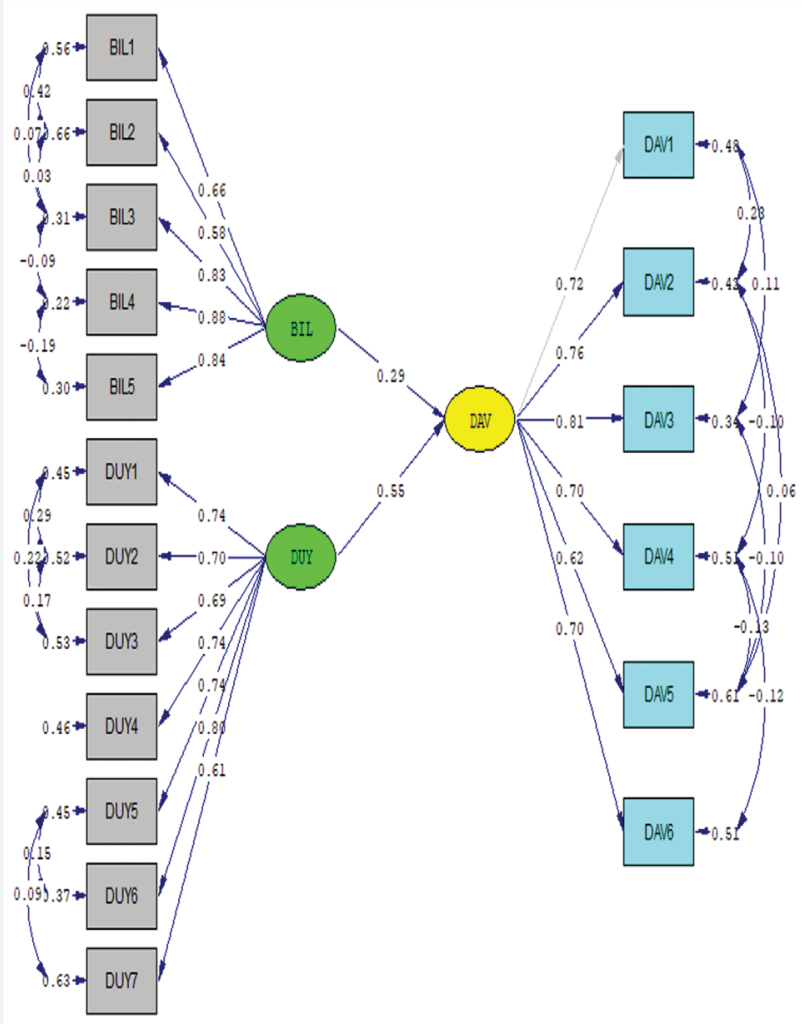

Chi-Square $=322.64, d f=108, \mathrm{p}-\mathrm{value}=0.00000, \mathrm{RMSEA}=0.046$

Figure 5. SEM model established with cognitive, affective and behavioral dimensions

BIL: Cognitive, DUY: Affective, DAV: Behavioral, RMSEA: Root mean square error of approximation

it meets the criterion of $X^{2} / d f=322.64 / 108=2.98<3$, which is among the criteria for goodness of fit.

According to Table 9, the CR and AVE values are 0.87 and 0.59 for the cognitive dimension factor, 0.88 and 0.52 for the affective dimension factor, and 0.87 and 0.52 for the behavioral dimension factor. The $C R$ value is expected to be greater than 0.70 and the AVE value to be greater than 0.50 and it is seen that the values calculated here are suitable for these criteria.

According to Table 10, the RMSEA (0.046), NFI (0.99), NNFI (0.99), CFI (0.99), SRMR (0.035), GFI (0.96) and AGFI (0.94) values of the SEM model are within the limits of excellent goodness of fit. On the other hand, the RMSEA (0.056) value of the attitude model is within the limits of acceptable goodness of fit, while the NFI (0.98), NNFI (0.98), CFI (0.99), SRMR (0.042), GFI (0.95) and AGFI (0.92) values are within the limits of excellent goodness of fit.

\section{Study Limitations}

The data set used in the study was obtained through a 5-point Likert-type scale (1 strongly disagree and 5 strongly agree) in 
Table 9. Findings on $\lambda, t$ value, $C R$ and $A V E$ values for cognitive, affective and behavioral dimension factors

\begin{tabular}{|c|c|c|c|c|c|}
\hline $\begin{array}{l}\text { Latent } \\
\text { variable }\end{array}$ & $\begin{array}{l}\text { Observed } \\
\text { variable }\end{array}$ & $\lambda$ & $t$ value & CR & AVE \\
\hline \multirow{6}{*}{ BIL } & - & - & - & \multirow{6}{*}{0.87} & \multirow{6}{*}{0.59} \\
\hline & BIL1 & 0.66 & 22.00 & & \\
\hline & BIL2 & 0.58 & 18.89 & & \\
\hline & BIL3 & 0.83 & 28.30 & & \\
\hline & BIL4 & 0.88 & 28.05 & & \\
\hline & BIL5 & 0.84 & 28.49 & & \\
\hline \multirow{7}{*}{ DUY } & DUY1 & 0.74 & 25.27 & \multirow{7}{*}{0.88} & \multirow{7}{*}{0.52} \\
\hline & DUY2 & 0.70 & 23.09 & & \\
\hline & DUY3 & 0.69 & 22.71 & & \\
\hline & DUY4 & 0.74 & 25.10 & & \\
\hline & DUY5 & 0.74 & 25.19 & & \\
\hline & DUY6 & 0.80 & 27.99 & & \\
\hline & DUY7 & 0.61 & 19.73 & & \\
\hline \multirow{6}{*}{ DAV } & DAV1 & 0.72 & 27.14 & \multirow{6}{*}{0.87} & \multirow{6}{*}{0.52} \\
\hline & DAV2 & 0.76 & 29.08 & & \\
\hline & DAV3 & 0.81 & 26.77 & & \\
\hline & DAV4 & 0.70 & 18.90 & & \\
\hline & DAV5 & 0.62 & 16.69 & & \\
\hline & DAV6 & 0.70 & 19.84 & & \\
\hline
\end{tabular}

CR: Composite reliabilit, AVE: Average variance extracted, BIL: Cognitive, DUY: Affective, DAV: Behavioral

Table 10. Findings related to goodness of fit criteria of SEM and attitude models

\begin{tabular}{|l|l|l|l|l|}
\hline $\begin{array}{l}\text { Goodness- } \\
\text { of-fit } \\
\text { criteria }\end{array}$ & Excellent fit & Acceptable fit & SEM & Attitude \\
\hline RMSEA & $\begin{array}{l}0<\mathrm{RMSEA} \\
<0.05\end{array}$ & $\begin{array}{l}0.05 \leq \mathrm{RMSEA} \\
\leq 0.10\end{array}$ & 0.046 & 0.056 \\
\hline $\mathrm{NFI}$ & $0.95 \leq \mathrm{NFI} \leq 1$ & $\begin{array}{l}0.90<\mathrm{NFI} \\
\leq 0.95\end{array}$ & 0.99 & 0.98 \\
\hline NNFI & $0.97 \leq \mathrm{NNFI} \leq 1$ & $\begin{array}{l}0.95 \leq \mathrm{NNFI} \\
\leq 0.97\end{array}$ & 0.99 & 0.98 \\
\hline CFI & $0.97 \leq \mathrm{CFI} \leq 1$ & $0.95 \leq \mathrm{CFI} \leq 0.97$ & 0.99 & 0.99 \\
\hline SRMR & $0 \leq \mathrm{SRMR}<0.05$ & $\begin{array}{l}0.05 \leq \mathrm{SRMR} \\
\leq 0.10\end{array}$ & 0.035 & 0.042 \\
\hline GFI & $0.95 \leq \mathrm{GFI} \leq 1$ & $\begin{array}{l}0.90 \leq \mathrm{GFI} \\
\leq 0.95\end{array}$ & 0.96 & 0.95 \\
\hline AGFI & $0.90 \leq \mathrm{AGFI} \leq 1$ & $\begin{array}{l}0.85 \leq \mathrm{AGFI} \\
\leq 0.90\end{array}$ & 0.94 & 0.92 \\
\hline $\begin{array}{l}\text { SEM: Structural equation modeling, RMSEA: Root mean square error of } \\
\text { approximation, NFI: Normed fit index, NNFI: Non-normed fit index, CFI: Comparative } \\
\text { fit index, SRMR: Standardized root mean square residual, GFI: Goodness of fit index }\end{array}$ \\
AGFI: Adjusted goodness of fit index, reference
\end{tabular}

addition to demographic questions, which was applied to a total of 958 individuals that could be reached across Turkey between 1-30 June 2020.

\section{DISCUSSION}

The negative effects of the COVID-19 pandemic, which is the biggest problem of today, on human life are increasing day by day. In this study, which was carried out on the observation that the attitudes of individuals in their previous lives differed during the pandemic period, the cognitive, affective and behavioral attitudes of individuals during the pandemic process, the relationships among these attitudes and the variables that affected the attitudes were examined.

It was determined that the affective dimension had the highest effect in the results of EFA, CFA and SEM analysis, which are among the statistical methods that are effective in examining the attitude of individuals towards an event with these subdimensions.

When the other findings obtained from the study were examined in terms of demographic characteristics, it was observed that, in the affective dimension, the averages of individuals who were women, aged 20-29 years, had an income level of 4001-7000 TL, had a primary school education level and those with individuals who were found to be positive for COVID-19 in their close environment were high. In terms of demographic characteristics in the cognitive dimension, it has been observed that the averages of women, those aged 19 years and under, those with an income level of 4001-7000 $\mathrm{TL}$, those with primary school education level and those with individuals with positive COVID-19 in their close environment were high.

Finally, in terms of demographic characteristics in behavioral dimension, it was observed that the averages of individuals who were female, aged between 40 and 49 years, had an income level of 7001-10000 TL, were primary school graduates, and had individuals without positive COVID-19 in their surroundings were higher.

As a result of SEM, it is seen that an increase of one unit in the affective dimensions of individuals causes an effect of 0.55 units in the behavioral dimensions, and an increase of one unit in the cognitive dimensions causes an increase of 0.29 units in the behavioral dimension.

While "individuals' questioning their purpose of life again" was the most effective item in the cognitive dimension, it was determined that individuals would be more sensitive individuals in the future than in the past and would attach importance to economic measures according to the items that were effective in the affective and behavioral dimensions.

\section{CONCLUSION}

It should not be forgotten that, like many pandemics in the past, the COVID-19 pandemic is a temporary process, even 
if it has negative effects on the attitudes and behaviors of individuals.

With the hope that the ongoing vaccine studies will yield positive results as soon as possible, all individuals should take responsibility for this pandemic to be overcome with the least damage for our country and the whole world humanity. In order to inform people about responsibilities, taking into account the results of this research, which is an attitude determination study, it is necessary to assimilate the causes and consequences of the changes in the attitudes and behaviors of individuals in this process to learn a lesson from all these experiences and make positive contributions to the future.

\section{Ethics}

Ethics Committee Approval: Study was approved by the decision of Afyon Kocatepe University Scientific Research and Publication Ethics Committee dated 27.05.2020 and numbered 15.06.2020-E.17011.

Informed Consent: It is a survey study.

Peer-review: Externally peer-reviewed.

\section{Authorship Contributions}

Concept: I.B., M.A., Y.D., C.G., S.S., Design: B.I., N.F., M.A., Y.D., C.G., S.S., Data Collection or Processing: B.T., M.D., S..B., C.G., S.S., Analysis or Interpretation: B.T., C.G., S.S., Literature Search: E.Ö., I.B., B.I., M.D., C.G., S.S., Writing: B.T., B.I., M.D., N.F., Ş.B., C.G., S.S.

Conflict of Interest: No conflict of interest was declared by the authors.

Financial Disclosure: The authors declared that this study received no financial support.

\section{References}

1. Honigsbaum M. Pandemic. Lancet. 2009;373:1939.

2. Morens DM, Folkers GK, Fauci AS. What is a pandemic? J Infect Dis. 2009;200:1018-21.

3. Last JM. Dictionary of Epidemiology. Fourth Edition. John M. Last, Robert A. Spasoff, and Susan S. Harris (edited). 2000.

4. Qiu W, Rutherford S, Mao A, Chu C. The Pandemic and its Impacts. Health, Culture and Society, Dec. 2017:1-11.

5. Morens DM, Taubenberger JK, Folkers GK, Fauci AS. Pandemic influenza's 500th anniversary. Clin Infect Dis. 2010;51:1442-4.

6. Madhav N, Oppenheim B, Gallivan M, Mulembakani P, Rubin E, Nathan Wolfe N, Pandemics: Risks, Impacts, and Mitigation" (Chapter 17 in Disease Control Priorities. Editors: Jamison D.T, Gelband H, Horton S, Jha, P, Laxminarayan R, Mock C.N and Nugent R, Third Edition, The World Bank Group, Washington: DC. 2018.

7. Cakır Z, Savas H.B. A mathematical modelling for the COVID-19 pandemic in Iran. Ortadogu Tip Dergisi. 2020;12:206-10.

8. Çobanoğlu N. Bireysel, Profesyonel, Toplumsal, Bilimsel ve Siyasal Etiği Yeniden Sorgulatan COVID-19 Pandemisi. Anatolian Clinic the Journal of Medical Sciences. 2020;25:36-42.
9. Sadique MZ, Edmunds WJ, Smith RD, Meerding WJ, de Zwart O, Brug J, et al. Precautionary behavior in response to perceived threat of pandemic influenza. Emerg Infect Dis. 2007;13:1307-13.

10. Brewer NT, Chapman GB, Gibbons FX, Gerrard M, McCaul KD, Weinstein ND. Meta-analysis of the relationship between risk perception and health behavior: the example of vaccination. Health Psychol. 2007;26:136-45.

11. de Zwart O, Veldhuijzen IK, Elam G, Aro AR, Abraham T, Bishop GD, et al Perceived threat, risk perception, and efficacy beliefs related to SARS and other (emerging) infectious diseases: results of an international survey. Int J Behav Med. 2009;16:30-40.

12. Siu W. Extended parallel process model and H5N1 influenza virus. Psychol Rep. 2008;102:539-50.

13. Norman P, Boer H, Seydel ER. Protection Motivation Theory. In Predicting health behaviour Edited by: Conner M, Norman P. Berkshire, UK: Open University Press, 2005;81-126.

14. Champion VL, Skinner CS. The Health Belief Model. In Health behaviour and health education; theory, research, and practice Edited by: Glanz K, Rimer BK, Viswanath K. San Francisco: CA: Jossey Bass, 2008;45-65.

15. Witte K. Fear as motivator, fear as inhibitor: Using the EPPM to explain fear appeal successes and failures. In The handbook of communication and emotion. Edited by: Andersen PA, Guerrero LK. New York: Academic Press. 1998;423-50.

16. Weinstein ND, Sandman PM, Blalock SJ. The Precaution Adoption Process Model. In Health behaviour and health education; theory, research, and practice Edited by: Glanz K, Rimer BK, Viswanath K. San Francisco: CA: Jossey Bass. 2008;123-47.

17. Kok $G$, Jonkers $R$, Gelissen $R$, Meertens $R$, Schaalma $H$, de Zwart 0 . Behavioural intentions in response to an influenza pandemic. BMC Public Health. 2010;10:174.

18. Poletti P. Human behaviour in epidemic modelling. PhD thesis. Dissertation, University of Trento. 2010.

19. Fenichel EP, Castillo-Chavez C, Ceddia MG, Chowell G, Parra PA, Hickling GJ, et al. Adaptive human behavior in epidemiological models. Proc Natl Acad Sci U S A. 2011;108:6306-11.

20. Enemark C. Pandemic pending. Australian Journal of International Affairs. 2006;60:43-9.

21. Donner WR, Rodriguez H, Diaz W. Public Warning Response Following Tornadoes in New Orleans, LA, and Springfield, MO: A Socialogical Anaysis. Second Symposium on Policy and Socio-economic Research. San Antonio, Texas: 2007.

22. Mileti D, Sorensen J. Communication of Emergency Public Warnings: A Social Science Perspective and State-of-the-Art Assessment. Washington DC: Federal Emergency Management Agency, 1990.

23. Hagan P, Maguire B, Bopping D. Public behaviour during a pandemic. The Australian Journal of Emergency Management. 2008;23:35-40.

24. Kağıtçıbaşı Ç. Yeni insan ve insanlar. 10. Baskı. İstanbul: Evrim Yayın Evi ve Bilgisayar San. Tic. Ltd. Şti. 2006.

25. Turgut MF, Baykul Y. Eğitimde Ölçme ve Değerlendirme. Ankara: Saydam Matbaacilık. 1992.

26. Aslan S, Yalçın M. Öğretmenliğe İlişkin Tutumun Beş Faktör Kişilik Tipleriyle Yordanması. Milli Eğitim Dergisi. 2013;197:169-79.

27. Fishbein M, Ajzen I. Beliefs attitude intention and behavior: An introduction to theory and research. Massachusetts, MA: Addison-Wesley. 1975.

28. Yaşar M. Eğitimde Ölçme ve Değerlendirme Dersine Yönelik Tutum Ölçeğinin Geliştirilmesi. Eğitim Bilimleri Araştırmaları Dergisi. 2014;4:259-79.

29. Smith MB. Attitude Change International Encyclopedia of the Social Sciences. Crowell and Mac Millan, 1968.

30. Turgut MF. Tutumların Ölçülmesi (DersNotu), No: 7, Ankara: Hacettepe Üniversitesi, 1977.

31. Petty RE, Cacioppo JT. The Elaboration Likelihood Model of Persuasion. Advences in Experimental Social Psychology. 1986;19:123-205. 
32. Kaplan A, İpek AS. Matematik Öğretmenliği Adaylarının Öğretmenlik Mesleğine Yönelik Tutumlarının incelenmesi. Eğitim ve Bilim, 2002;27:6973.

33. Thurstone LL. Attitudes Can Be Measured Readings In Attitude Theory And Measurement. Ed: Martin Fishbein. New York: John Wiley\&tSons, Inc. 1967;77-89.

34. Tepe D, Öğrencilerin Fen Derslerine Karşı Tutumları ile Başarıları Arasındaki ilişki. Yayınlanmamış Yüksek Lisans Tezi. Ankara: Hacettepe Üniversitesi, 1999.

35. Tay B, Tay BA. Sosyal Bilgiler Dersine Yönelik Tutumun Başarıya Etkisi. Türk Eğitim Bilimleri Dergisi. 2006;4:73-84.

36. Koç E. Tüketici Davranışı ve Pazarlama Stratejileri: Global ve Yerel Yaklaşım. Seçkin Yayıncılık, Ankara: 2007.

37. Özgüven N. Tüketicilerin Online Alışverişe Karşı Tutumları ile Demografik Özellikleri Arasındaki İlişkinin Analizi. Karamanoğlu Mehmetbey Üniversitesi Sosyal ve Ekonomik Araştırmalar Dergisi. 2011;2011:47-54.

38. Bloom BS. İnsan Nitelikleri ve Okulda Öğrenme. (Çev. D. Ali Özçelik), İstanbul: Milli Eğitim Basımevi. 1995.

39. Odabaşı Y, Gülfidan B. Tüketici Davranışı. Medicat Akademi. İstanbul, 2002.

40. Stapleton CD. Basic Concepts And Procedures Of Confirmatory Factor Analysis. Paper Presented At The Annual Meeting Of The Southwest Educational Research Association, January 23-25 1997.

41. Rennie KM. Exploratory And Confirmatory Rotation Strategies in Exploratory Factor Analysis. Paper Presented At The Annual Meeting Of The Southwest Educational Research Association, 1997.

42. Büyüköztürk Ş. Faktör analizi: Temel kavramlar ve ölçek geliştirmede kullanımı. Kuram ve Uygulamada Eğitim Yönetimi Dergisi. 2002;32:470-83.

43. Bollen KA, Long JS. Testing structural equation models. Sage, Newbury Park, CA:1993.

44. Maruyama GM. Basics of Structural Equation Modeling. SAGE Publications. Inc;1998.

45. Yılmaz V, Çelik HE, Bankacılık Sektöründe Müșteri Memnuniyeti ve Bankaya Bağlılık Arasındaki İlişkinin Yapısal Eşitlik Modelleriyle Araştırılması. VII. Ulusal Ekonometri ve İstatistik Sempozyumu. İstanbul: 2005.

46. Pang NSK. School values and teachers feelings: a LISREL model. Journal of Educational Administration. 1996;34:64-83.

47. YIImaz V. Consumer behavior of shopping center choice. Social Behavior and Personality. 2004;32:783-90.

48. Rigdon EE. Structural equation modeling In GA Marcoulides (Ed.), Modern methods for business research, New Jersey: Lawrence Erlbaum, 1998;25194.

49. Çınar í, Saraçlı S. Öğretmenlerin Örgütsel Bağlılık ve Motivasyonları Arasındaki ïlişkinin Incelenmesi: Çay ilçesi örneği". International Online Journal of Education Sciences. 2015;7:266-81.

50. DeWitte SN. Mortality risk and survival in the aftermath of the medieval Black Death. PLoS One. 2014;9:e96513.

51. Platt C. King Death: The Black Death and Its Aftermath in Late-Medieval England. Oxon, U.K.: Routledge;2014.

52. Jones DS. The persistence of American Indian health disparities. Am J Public Health. 2006;96:2122-34.

53. Diamond J. Guns Germs and Steel: The Fates of Human Societies. New York: Norton. 2009.
54. Chisholm H. Cholera. Encyclopedia Britannica. 1911;11:265-6.

55. Frieden NM. The Russian cholera epidemic, 1892-93, and medical professionalization. J Soc Hist. 1977;10:538-59.

56. Johnson NP, Mueller J. Updating the accounts: global mortality of the 1918-1920 "Spanish" influenza pandemic. Bull Hist Med. 2002;76:105-15.

57. McKibbin WJ, Sidorenko AA. Global Macroeconomic Consequences of Pandemic Influenza.Analysis, Lowy Institute for International Policy. Sydney: Australia. 2006.

58. Viboud C, Simonsen L, Fuentes R, Flores J, Miller MA, Chowell G. Global Mortality Impact of the 1957-1959 Influenza Pandemic. J Infect Dis. 2016;213:738-45.

59. Mathews JD, Chesson JM, McCaw JM, McVernon J. Understanding influenza transmission, immunity and pandemic threats. Influenza Other Respir Viruses. 2009;3:143-9.

60. Kavet J. A perspective on the significance of pandemic influenza. Am J Public Health. 1977;67:1063-70.

61. WHO (World Health Organization), Situation Report: Zika Virus, Microcephaly, Guillain-Barre Syndrome. Weekly data report. February 2 1977.

62. Dixon S, McDonald S, Roberts J. AIDS and Economic Growth in Africa: A Panel Data Analysis. Journal of International Development. 2001;13:411-26.

63. Wang MD, Jolly AM. Changing virulence of the SARS virus: the epidemiological evidence. Bull World Health Organ. 2004;82:547-8.

64. Keogh-Brown MR, Smith RD. The economic impact of SARS: how does the reality match the predictions? Health Policy. 2008;88:110-20.

65. Dawood FS, Iuliano AD, Reed C, Meltzer MI, Shay DK, Cheng PY, et al. Estimated global mortality associated with the first 12 months of 2009 pandemic influenza A H1N1 virus circulation: a modelling study. Lancet Infect Dis. 2012;12:687-95.

66. Kim YW, Yoon SJ, Oh IH. The economic burden of the 2009 pandemic H1N1 influenza in Korea. Scand J Infect Dis. 2013;45:390-6.

67. Arabi YM, Balkhy HH, Hayden FG, Bouchama A, Luke T, Baillie JK, et al. Middle East Respiratory Syndrome. N Engl J Med. 2017;376:584-94.

68. Jun K. MERS Outbreak Prompts South Korean Stimulus Package. Wall Street Journal. 2015;25.

69. Park JM, Kim J. Hong Kong Sets 'Serious' Response to South Korea's MERS Outbreak, Reuters. June 82015.

70. WHO. Ebola Situation Report, Weekly data report. April 152016.

71. World Bank, The Economic Impact of the 2014 Ebola Epidemic: Short and Medium Term Estimates for Guinea, Liberia, and Sierra Leone Working, 2014;90748, World Bank, Washington, DC.

72. UNDP (United Nations Development Programme), A Socio-Economic Impact Assessment of the Zika Virus in Latin America and the Caribbean: With a Focus on Brazil, Colombia, and Suriname. Synthesis report, UNDP, New York. 2017.

73. Schermelleh-Engel K, Moosbrugger $H$, Müller H. Evaluating the fit of structural equation models: Tests of significance and descriptive goodnessof-fit measures. Methods of Psychological Research. 2003:8;23-74. 